\title{
A Brief Minireview of poly-triazole: Alkyne and Azide Substrate Selective, Metal-catalyst Design
}

Jingpei Huo*, Shu-ni Wang, Yongpeng Liang, Xiaohong Hu, Qianjun Deng and Dongchu Chen* Institute of Electrochemical Corrosion, College of Materials Science and Energy Engineering, Foshan University, Foshan, 528000, P. R. China.

KEYWORDS. Click chemistry; poly-triazole; alkyne and azide

\begin{abstract}
Organic compounds that contain poly-triazole are very important intermediates in pharmaceutical and chemical industry. Click chemistry is one of essential reactions that can form $C-N$ bond with high atom economy. The research progress in metals catalyzed Click chemistry of azides and alkynes from the perspective of reaction mechanism is categorized and summarized.
\end{abstract}

\section{CONTENTS}

\section{Introduction}

2. The effects of different compounds containing alkyne 


\section{1 Mono-alkyne}

\subsection{Triyne}

\subsection{Fourfold-yne}

\subsection{Other alynls}

3. The effects of different compounds containing azide

\subsection{Mono-azide}

\subsection{Per-azide}

\subsection{Fourfold-azide}

\section{Conclusion and outlook}

\section{Author Information}

\section{Acknowledgement}

\section{References}

\section{Introduction}

Click chemistry is one of the research frontiers and hotspots in polymer chemistry. ${ }^{1,2}$ In recent years, copper-catalysed azide-alkyne cycloadditions (CuAAC) have attracted more and more attention, generating poly-1,2,3-triazole. ${ }^{3,4}$ It is extraordinary convenient to insert alkynyl or azide groups into biological molecules, applying for biomedicine and functional materials. ., 6 
Since 2001, Sharpless has reported by $\mathrm{Cu}$ (I) catalysis, alkynyl and azide-based reaction rate can be improved as much as 104 times, also found in the price of copper ion catalytic. ${ }^{7,8}$ Huisgen 1, 3-dipolar cycloaddition reaction possess a large number of advantages, including under mild conditions, highly productive yield..$^{9}{ }^{10}$ It doesn't even need for special separation, purification, accounting for alkyne groups coordination with copper, so as to improving the reactivity of alkynyl. ${ }^{11,12}$ Along with high regioselectivity, carbon atoms are coordinated on the electron cloud density change without end group of copper ion catalytic acetylene and azide. ${ }^{13,14}$ In most cases, the 3 -dipole ring addition reaction is not regionally selective and the reaction is slow. ${ }^{15,} 16$ Biomolecules have hardly reacted with azide and alkyne group, due to the weak polarity of the latter two ones. ${ }^{17,18}$ Significantly, those groups are easily connected with each other. More importantly, click reaction has a high degree of chemical selectivity, employing for modifying highly functional biological molecules, such as polypeptides, etc. ${ }^{19-21}$ Moreover, generating polytriazole group is relatively stable in the sequent reaction, remaining permanent under the conditions of acid, base and redox..$^{22-24}$

As for those merits, it is widely used in medical medicine and scientific materials for their versatility and reliability of synthetic reactions. ${ }^{25}$ In this review, we will mostly focus on recent developments in the effects of different substrates containing azide and alkyne. Based on our research, ${ }^{26-31}$ usage of the term click reaction is not only including the substrate classes of monoalkyne, diyne, triyne, fourfold-yne, mono- azide, diazide, triazide and fourfold-yne, but extended to structurally related compounds with selective, reactivity and productive yield, etc. Moreover, marco-molecular click reactions will be mentioned as well if they are necessary for the discussion or might act as springboard for future research. 


\section{The effects of different compounds containing alkyne}

Alkynes are classified as a new material, pharmaceutical intermediates, nanometer molecular devices as well as the important to build the skeleton in natural product synthesis. ${ }^{32,33}$ One of the most commonly used synthetic macromolecular triazole is a method of terminal alkynes and sodium azide as raw material, the $\mathrm{Cu}$ (I) catalytic Click reaction to finish. ${ }^{34,35}$ The method can get high yield of target product, so the alkyne class substrates play a very important role in the middle of the Click reaction. ${ }^{36,37}$

\subsection{Mono-alkyne}

Mono-alkynes have broad application prospects in the Click reaction. ${ }^{38}$ At the same time, single alkynes compounds are also a kind of plant secondary metabolites to resist various diseases and pests. ${ }^{39}$ Thousands of alkynes compounds have been isolated from 19 families of higher plants and basidiomycetes of lower plants, among which PGMA is a typical representative. ${ }^{40}$

Zhang et $\mathrm{al}^{41}$ under the action of catalyst $\mathrm{CuBr} / \mathrm{NHPMI}$ success, will be the end of the containing side chain containing azobenzene azide with mono-alkyne 1 (PGMA, Scheme 1) through efficient Click reaction, side chain was synthesized at room temperature of liquid crystal polymer containing azobenzene, molecular weight can be as high as $303000 \mathrm{Da}$, also found that such a large molecular weight almost does not affect the height of the polymer solution reversible photosensitivity, they predicted that is widely used because of its high molecular weight and optics and has very good mechanical performance of optoelectronic devices 


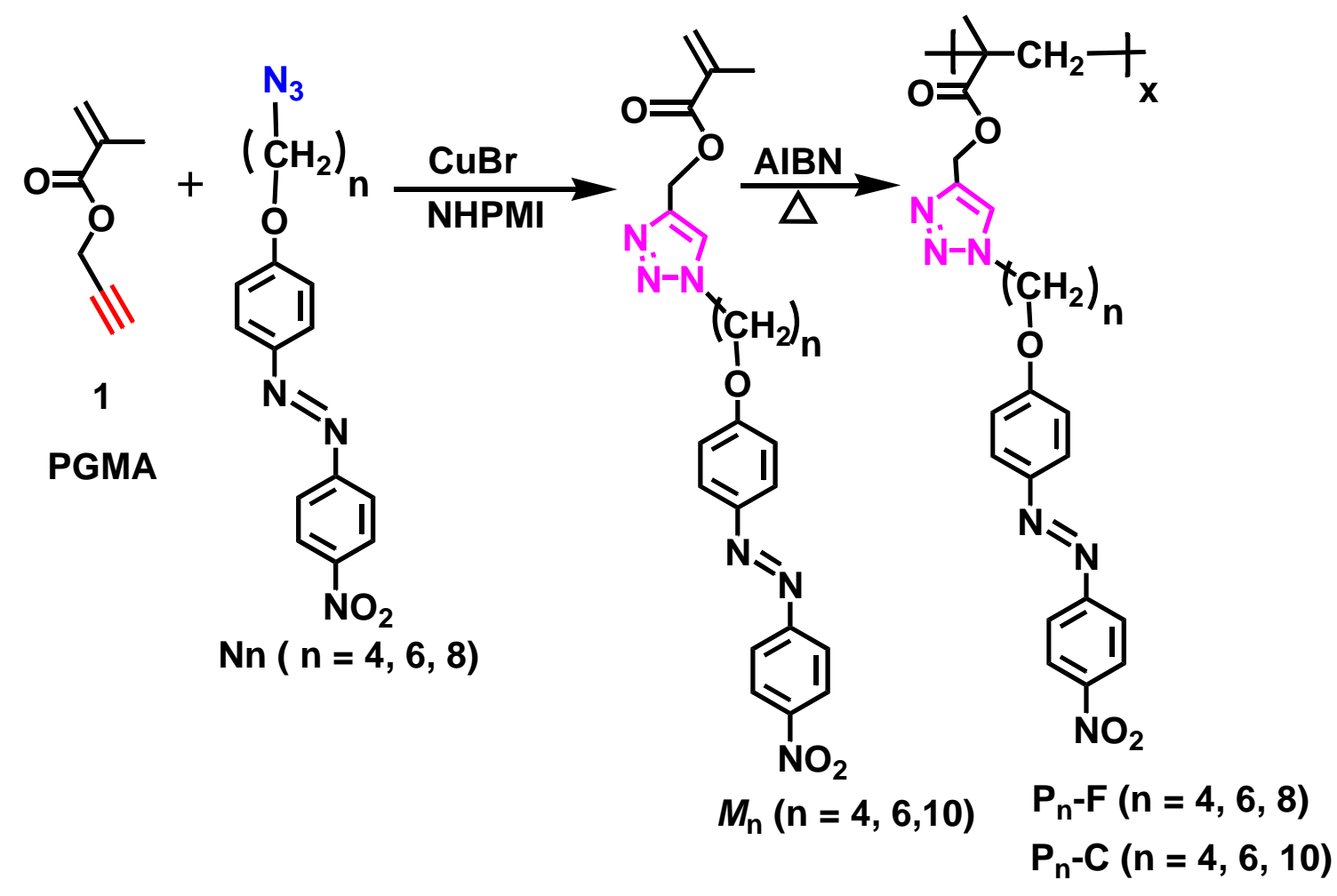

Scheme 1

For example, Zhao et $\mathrm{al}^{42}$ used the $\mathrm{CuBr} / \mathrm{PMDETA}$ catalytic system, which enables the endgroup acetylene $\mathbf{2}$ (Scheme 2) containing multi-functional methyl methacrylate to carry out the click reaction efficiently at room temperature.

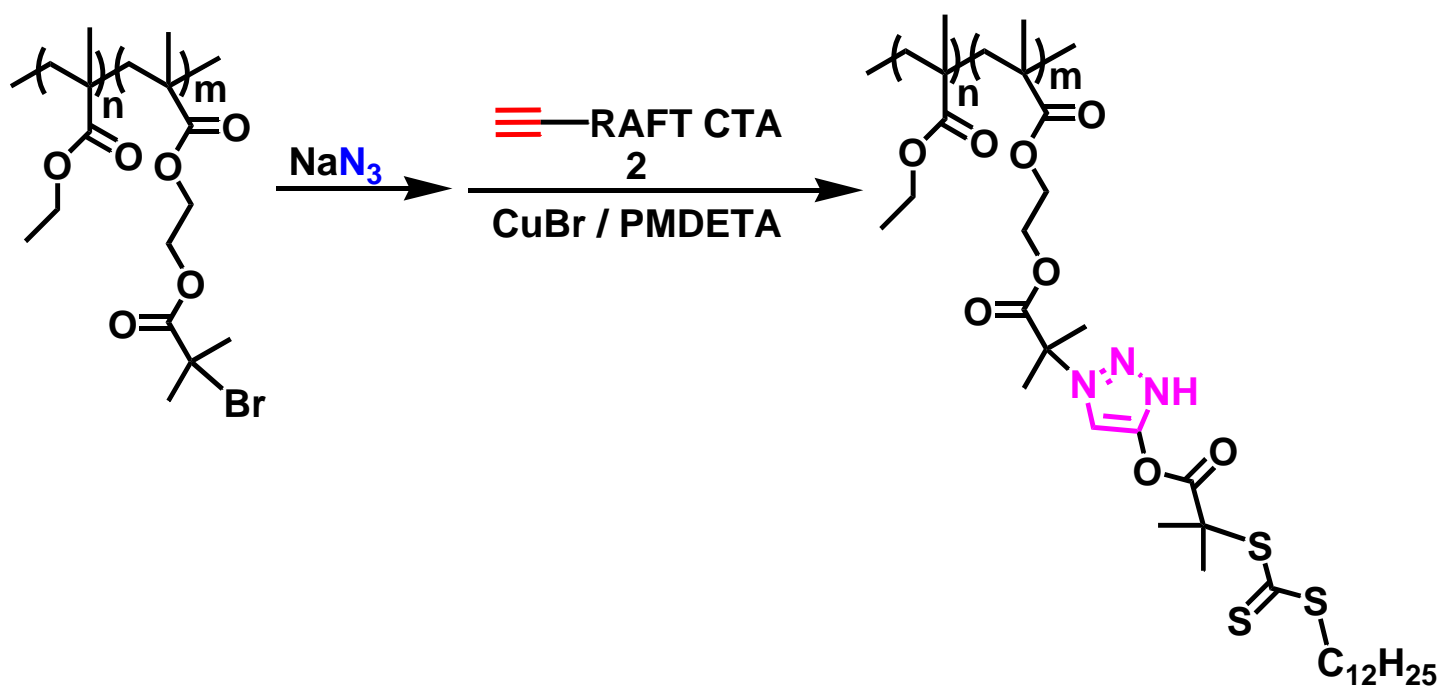




\section{Scheme 2}

On the other hand, Hughes et $\mathrm{al}^{43}$ by comparing with $\mathrm{Cu}$ (I) catalysts in the 1, 3-dipolar cycloaddition click chemistry based on substrate $\mathbf{3}$ (Scheme 3), found with $\mathrm{Cu}$ catalyst and after ${ }^{t} \mathrm{BuOH}$ under the condition of $\mathrm{H}_{2} \mathrm{O}$ is $1: 2$, the triazole dimerization product rate is the highest, and on this condition, can further to maximize the efficiency of aggregate into a series of racemic oligomer, the 1,2, 3-triazole polymers is expected to become a potential peptide analogues, widely used in biological materials.

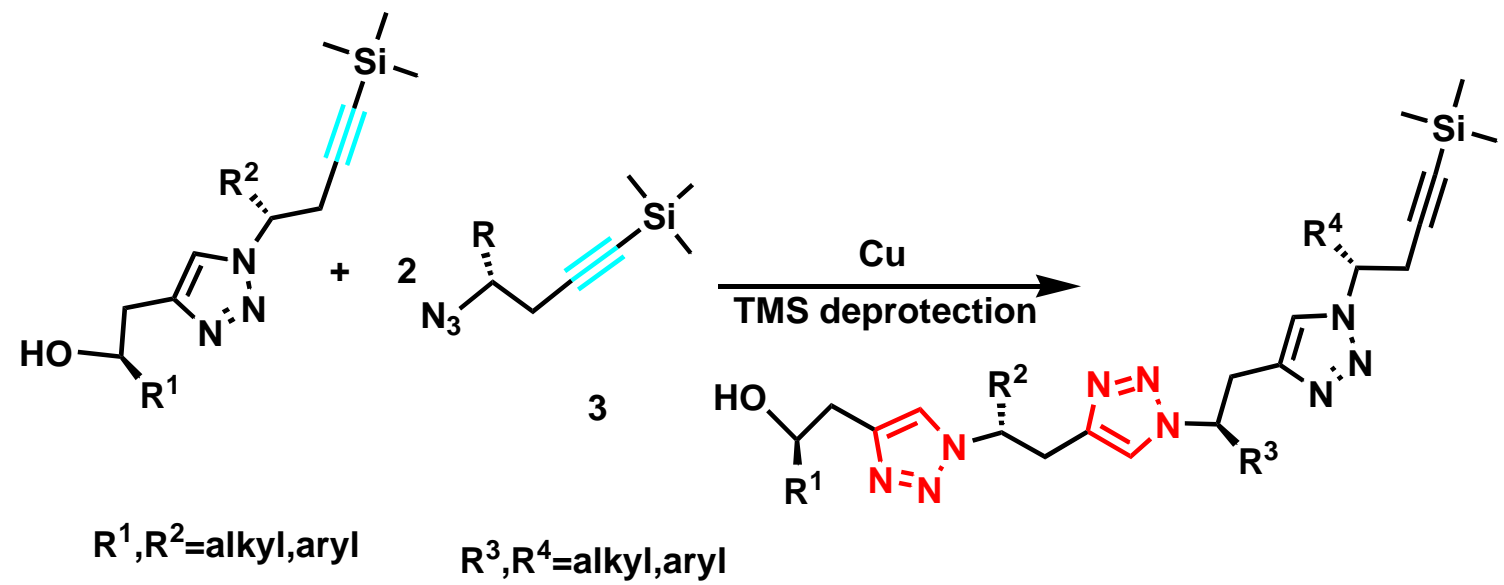

\section{Scheme 3}

Click chemistry in recent years showed a good compatibility between functional groups and can be performed at room temperature, Muller team ${ }^{44}$ is further combined with the ATRP technology used to successfully prepared a series of linear or branched chain containing half siloxane star or telechelic triazole polymer, among them, the more difficult is half as many as one of the substrate 4 containing siloxane acetylenic compounds, the synthesis of Muller using ATRP technology has been successfully synthesized, etc. Due to the unique nanocage structure and 
excellent solubility of the side chain containing sesquioxide, these triazole polymers are currently widely used in the field of materials science.

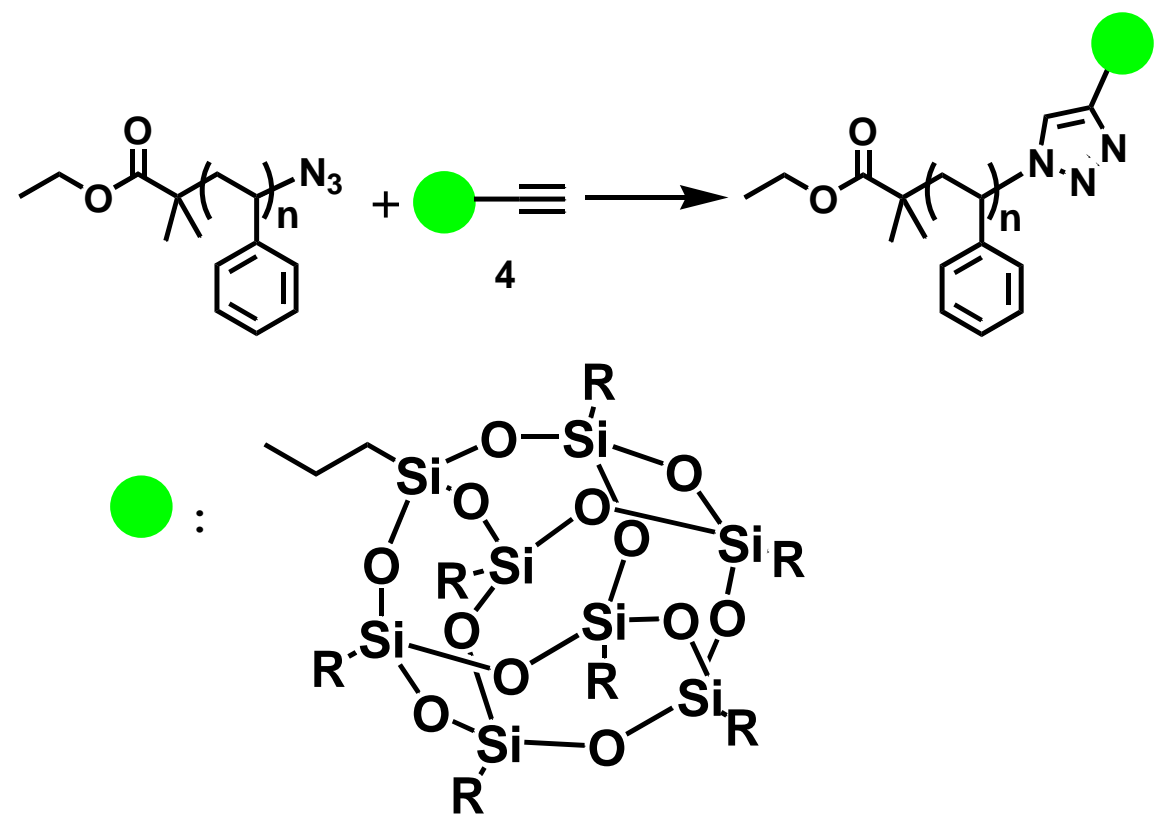

Scheme 4

Recently, owollik et $\mathrm{al}^{45}$ reported the CuI/DMF catalytic system, can make the end group containing modular conjugate ferrocene acetylene 5 (Scheme 5) effectively for the Click reaction under $50{ }^{\circ} \mathrm{C}$, the liquid phase synthesis of the triazole derivatives were obtained can be used as high temperature resistant adhesive materials.

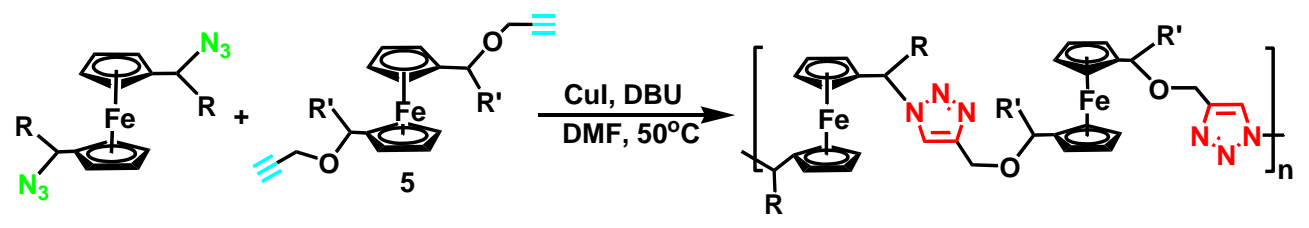

Scheme 5

$\mathrm{Xu}$ et $\mathrm{al}^{46}$ has been successful in catalyst under the catalysis of $\mathrm{CuBr}-\mathrm{TEMED} / \mathrm{DMSO}$ will contain diyne 6 (Scheme 6) and zwitterionic monomer DMPS-N $\mathrm{N}_{3}$ by click reaction under $\mathrm{N}_{2}$ by 
using a novel and efficient synthesis under $60{ }^{\circ} \mathrm{C}$ the triazole macromolecules. Due to its zwitterionic groups, it is expected to be used in biomedical applications.

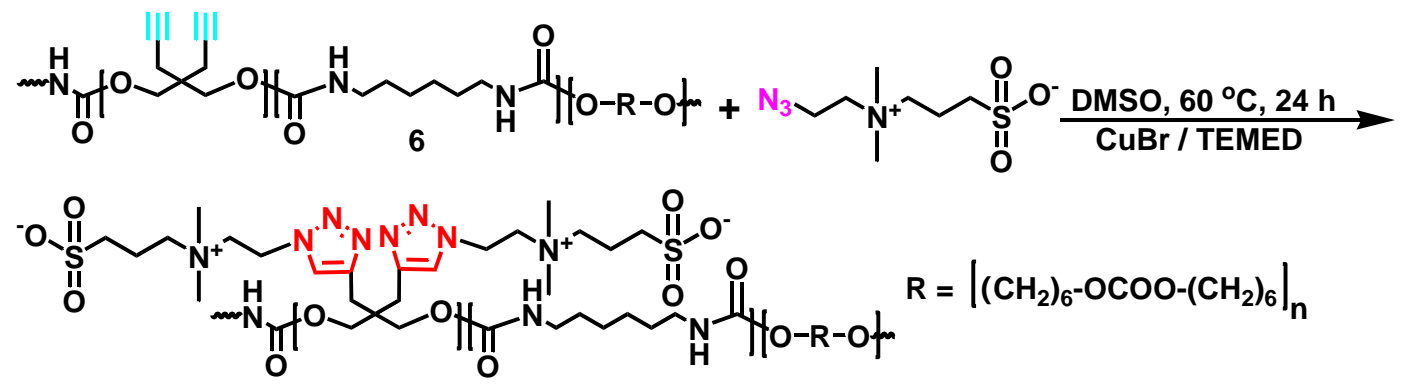

\section{Scheme 6}

Feng et $\mathrm{al}^{47}$ successfully synthesized poly-triazole macromolecules containing silenyl and phenylene by using $\mathrm{CuI}$ as catalyst in a polar solvent DMF and pyridine mixture by click reaction of 1, 4-azapenzene and diethylenyl silane 7 with a quantum yield ranging from 0.19 to 0.37 . This synthesis method provides a mild and low-cost way to obtain optical polymer materials containing organosilicon

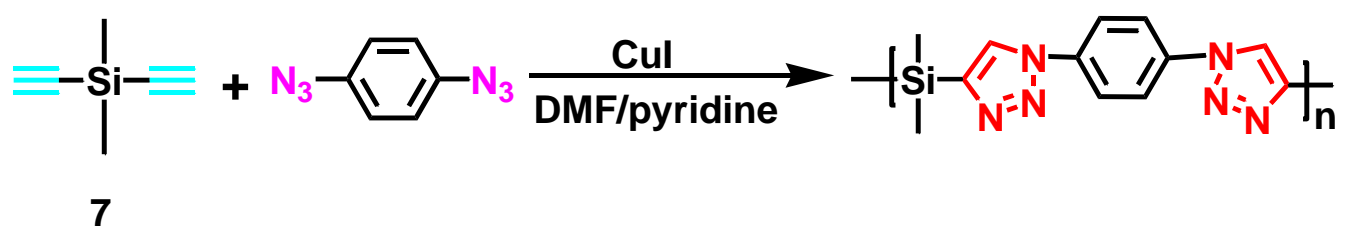

\section{Scheme 7}

In 2010, Khosravi et $\mathrm{al}^{48}$ with $\mathrm{Cu}$ wire as catalyst, in a mixture of 4:1 tetrahydrofuran is mixed with water and solvent, the hydrophobic functional two azide trehalose and chain terminal for two polyethylene glycol (peg) click on the polymerization reaction of diyne $\mathbf{8}$, reaction conditions for the reaction under $60{ }^{\circ} \mathrm{C}$ for 24 hours, get the new type of intelligent temperature response 
three azole linear sugary polymer, the temperature response of the polymer is mainly applied to medical materials (Scheme 8).

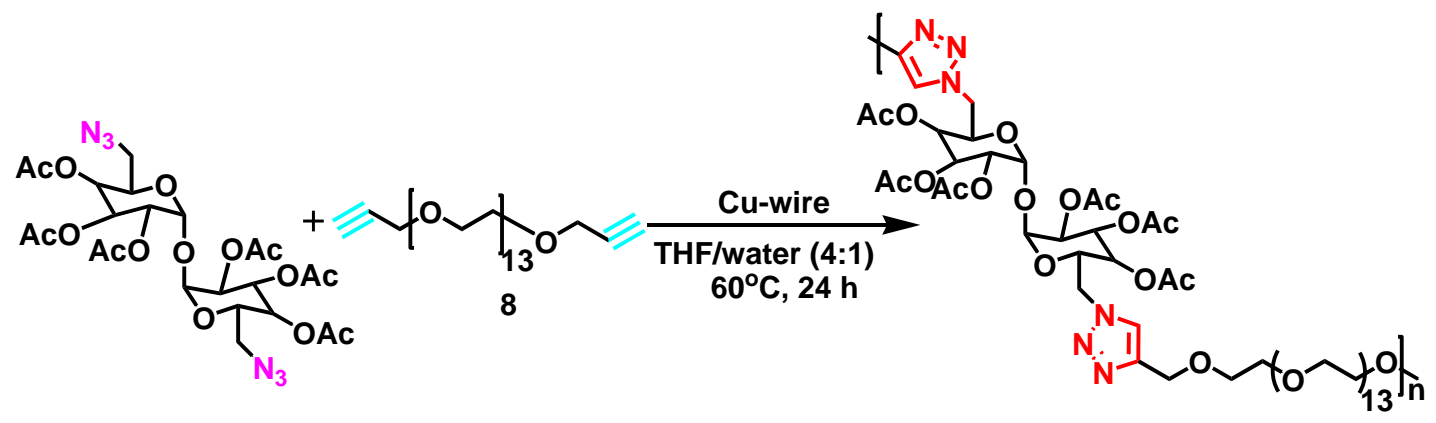

Scheme 8

In 2008, the Qing et $\mathrm{al}^{49} \mathrm{Cu}^{+}$as catalyst, make more glycol 2 azide with diyne 9 (Scheme 9) containing eight fluorine cyclobutane reaction completely under temperature of $80{ }^{\circ} \mathrm{C}$, generate more triazole fluoropolymer, high production rate, thermal stability is strong, in the most polar solvent with good solubility, but this is the most polymers are crystal shape. This fluoropolytriazole polymer has attracted extensive interest in advanced heat, oxidation, chemical corrosion, and insulation materials

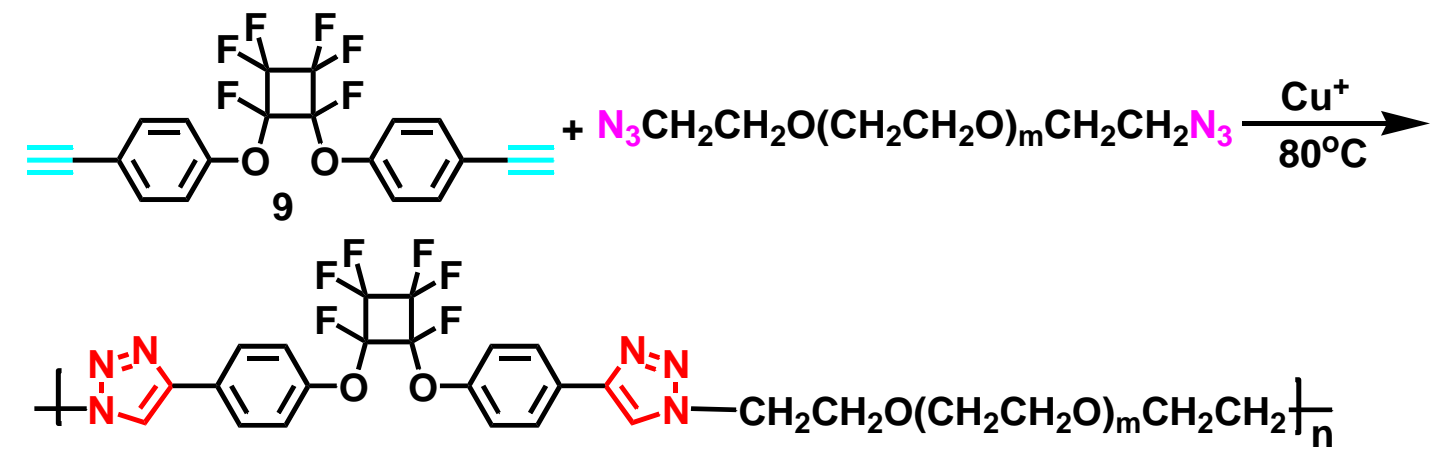

Scheme 9

\subsection{Triyne}


Tunca et $\mathrm{l}^{50}$ using $\mathrm{CuBr} / \mathrm{PMDETA}$ catalytic system, in the mixed solvent of DMF and THF, with many functional groups can make three phenyl propyl ether of acetylene compound $\mathbf{1 0}$ with polyhedral oligomeric times half siloxane single-ended base azide efficiently for the click reaction at room temperature (Scheme 10), its liquid phase synthesis of the triazole derivatives products rate is as high as $94 \%$, can be used in the field of biological materials

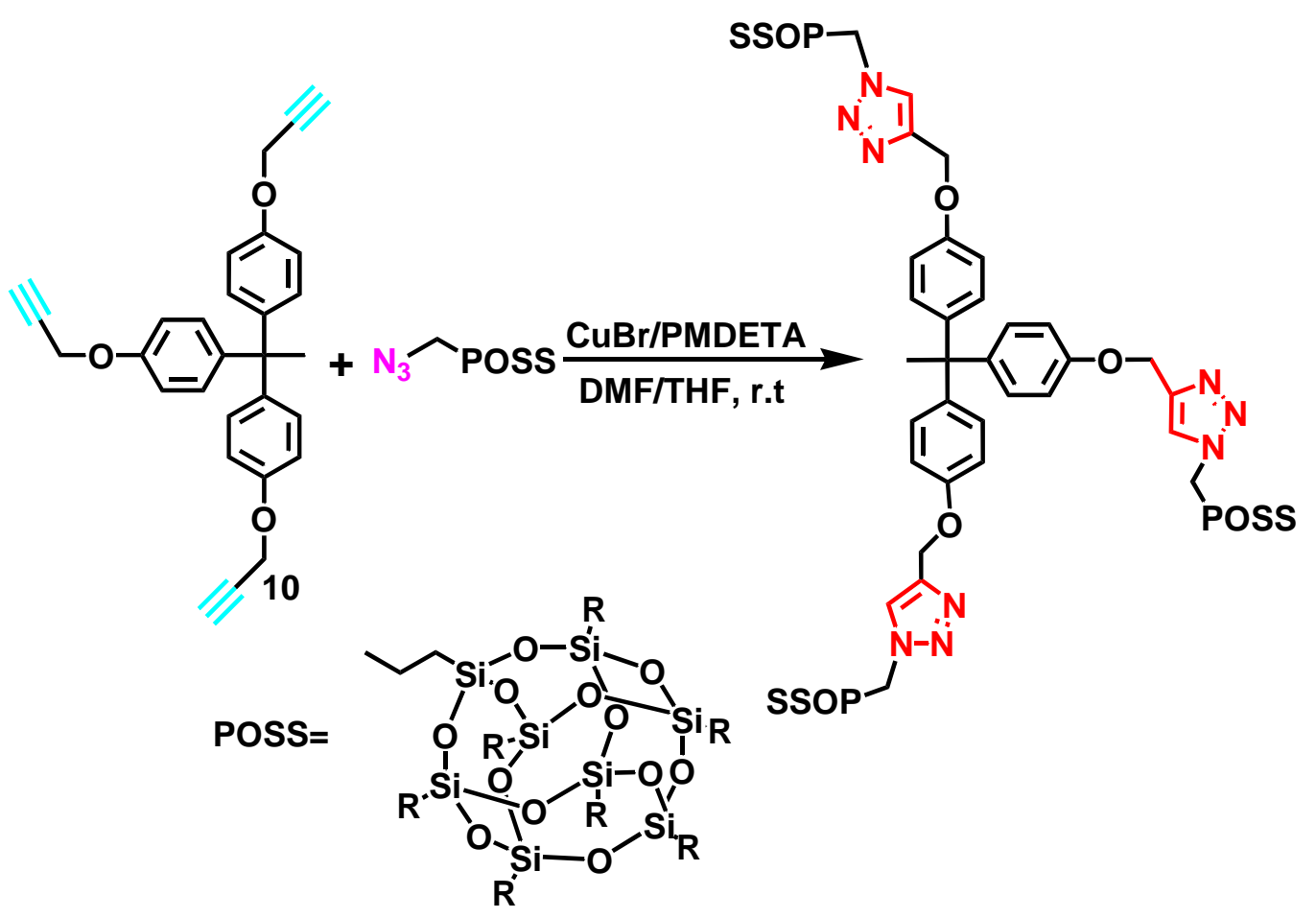

Scheme 10

Bhaumik et $\mathrm{al}^{51}$ took advantage of $5 \mathrm{~mol} \% \mathrm{CuI}$ catalytic system, in the mixed solvent of DMF and $\mathrm{Et}_{3} \mathrm{~N}$, can make the arc three azide and cup-type mesoporous triacetylene 11 (Scheme 11) compounds containing multiple functional groups and efficiently for the click reaction at room temperature, the liquid phase synthesis of mesoporous pyrrolidine triazole derivatives were molecular weight is not very big, but it continued to react with 4-aminopyridine can make its chain growth, and generate the three azole mesoporous molecular, now can be used as a new type 
of non-metallic organic catalysts applied in the Michael addition reaction, It is an important research direction of sustainable chemical synthesis in the future.

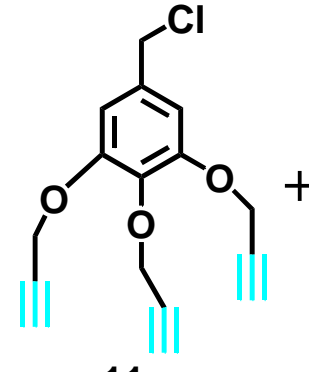

11

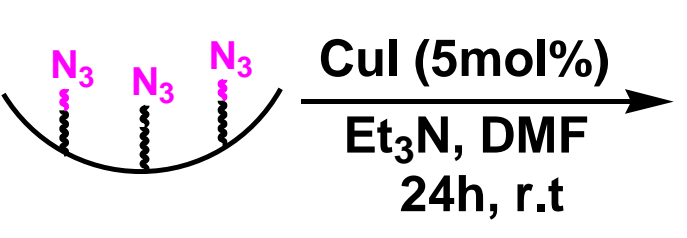

24h, r.t

Scheme 11

Lonnberg et $\mathrm{al}^{52}$ used $\mathrm{CuSO}_{4}$-sodium asorbate/1, 4-dioxane catalytic system, which can make the triacetylene 12 (Scheme 12) containing benzaldehyde and tetraether react with glycoazide by Click at room temperature. The yield of triazole glycocluster synthesized by the system reached $57 \%$, which can be applied in the field of medical medicine.

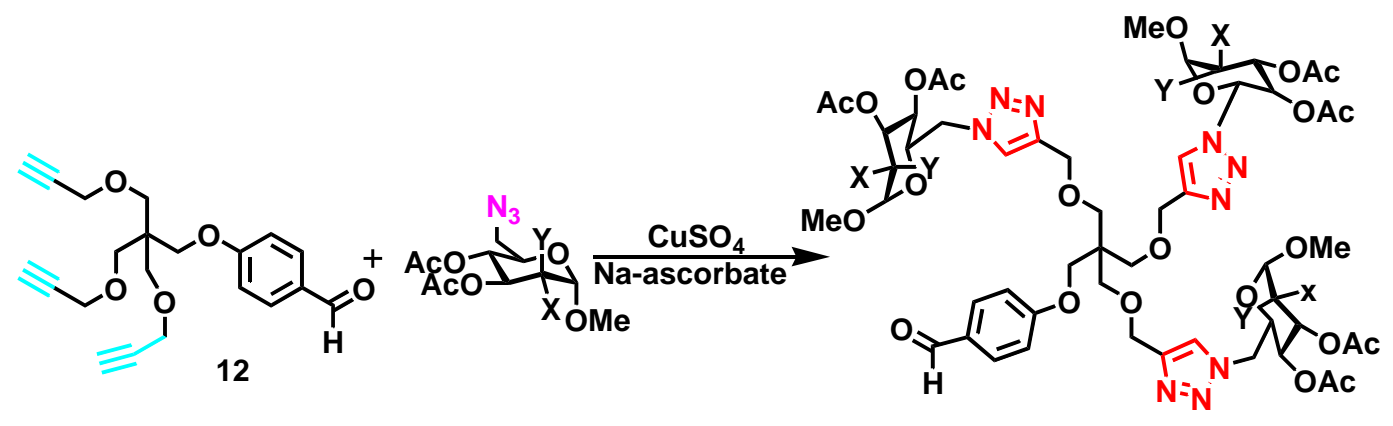

\section{Scheme 12}

Tang et $\mathrm{al}^{53}$ studied a lot of the literature of Click chemistry, deformation of small molecules found in the development of new polymerization is a valuable resource, for example by $\mathrm{CuI}$ catalytic system, can make the tri-acetylene compound 13 (Scheme 13) and Permian nitrogen 
compounds to efficiently to click polymerization at room temperature, generating more than rules of linear macromolecular triazole, but they found the nonmetal catalyst polymerization, great progress has been made in recent years, this kind of catalyst is more advantageous to the rules of the functional structure of linear macromolecular synthesis. They play an important role in the synthesis of functional materials.

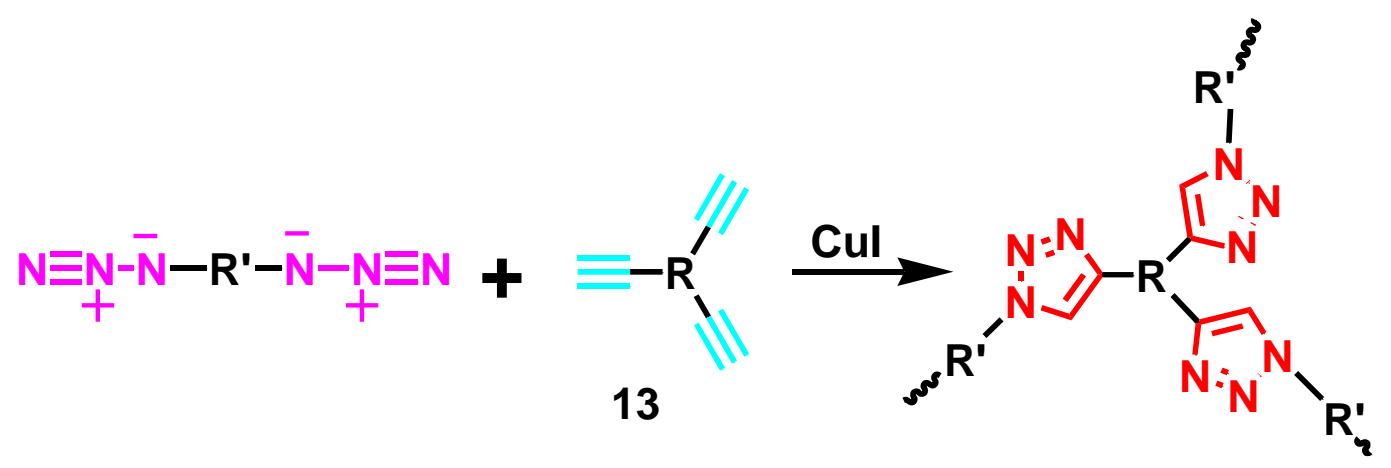

Scheme 13

Shen et $\mathrm{al}^{54}$ the $\mathrm{CuSO}_{4} \cdot 5 \mathrm{H}_{2} \mathrm{O}$ and sodium ascorbic acid as catalyst, at room temperature, make the Permian nitrogen amino nitro azide ethyl benzene and benzene ether base three propiolic 14 (Scheme 14) click reaction efficiently, of the liquid-phase synthesis of the second order of the groups of linear optical many-branched triazole production rate of $59.2 \%$, more than the corresponding linear triazole molecule low $9.1 \%$, the molecular weight of 7400 , a linear low of 600 , but in common organic solvents has good solubility and thermal stability, the three dimensional space and more independent branch structure and ethinyl crosslinking structure at the end, Therefore, it is likely to play an important role in nonlinear optical materials in the future. 


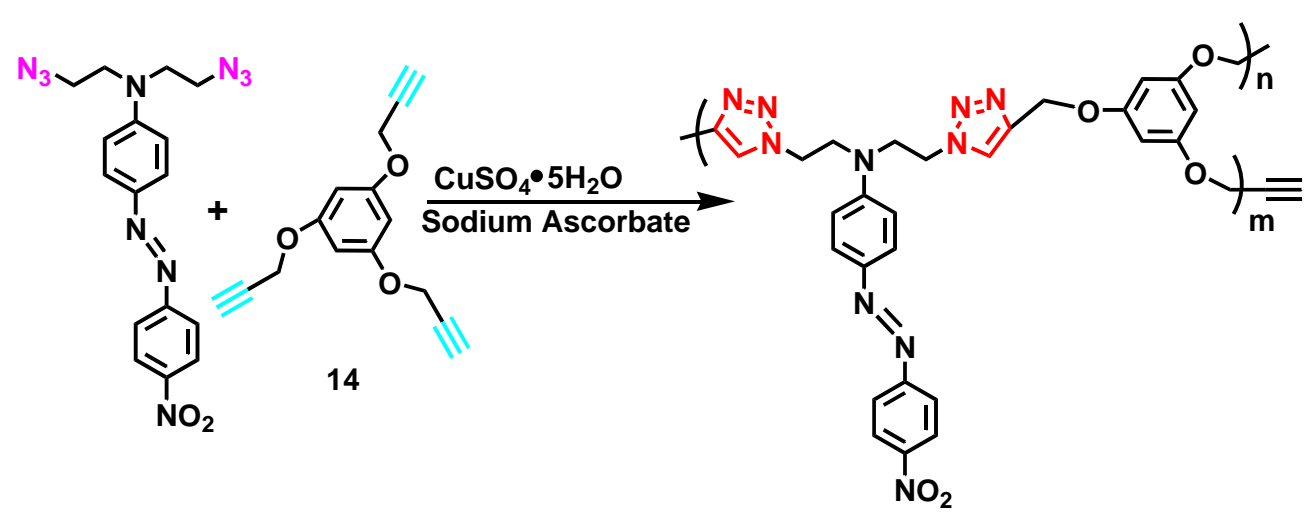

\section{Scheme 14}

\subsection{Fourfold-yne}

Duran $^{55}$ in the absence of water environment, such as the choice of different filler agent, the cross-linking agent for acetylene derivatives 15 (Scheme 15) to propiolic acid methyl ester and the Permian nitrogen compounds in the click reaction under $55^{\circ} \mathrm{C}$, the synthesis of three azole macromolecules can be applied to a potential rocket propellant binder and different proportions of stuffing agent for generating crosslinking different mechanical properties of polymers, and has a filler agent processing properties of polymers and the coefficient is better than that of the packless agent, especially in alumina filler agent is preferred.

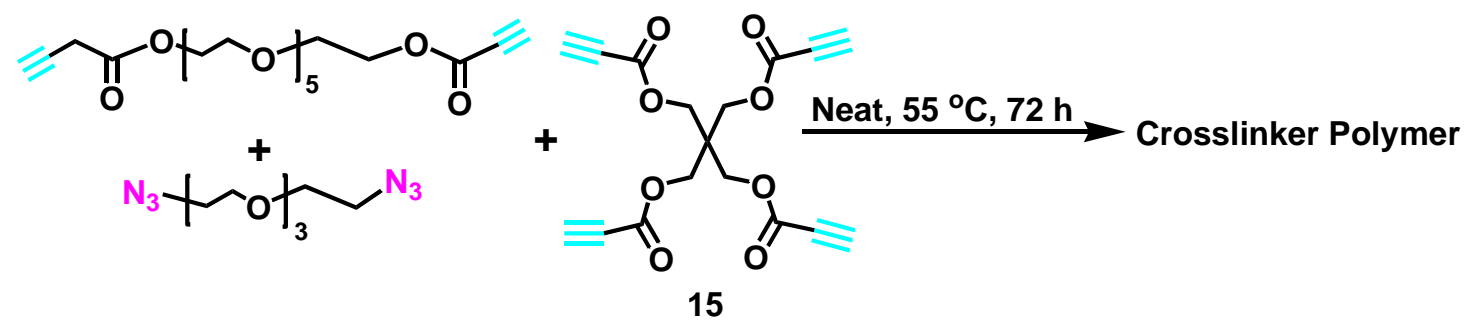

Scheme 15

$\mathrm{Kolb}^{56}$ reported, $\mathrm{CuSO}_{4} /$ ascorbic acid sodium/DMF catalytic system, the cyclodextrin azide and fourfold alkyne 16 (Scheme 16) under microwave radiation to $90{ }^{\circ} \mathrm{C}$ in the click 
polymerization for an hour, the liquid phase synthesis of three azole macromolecular production rate is as high as $74 \%$, the molecular weight of 5409.79 , can further and adamantane calcein compound reaction, preparation of new fluorescent wire at the same time can also be applied in the field of fluorescent dyes.

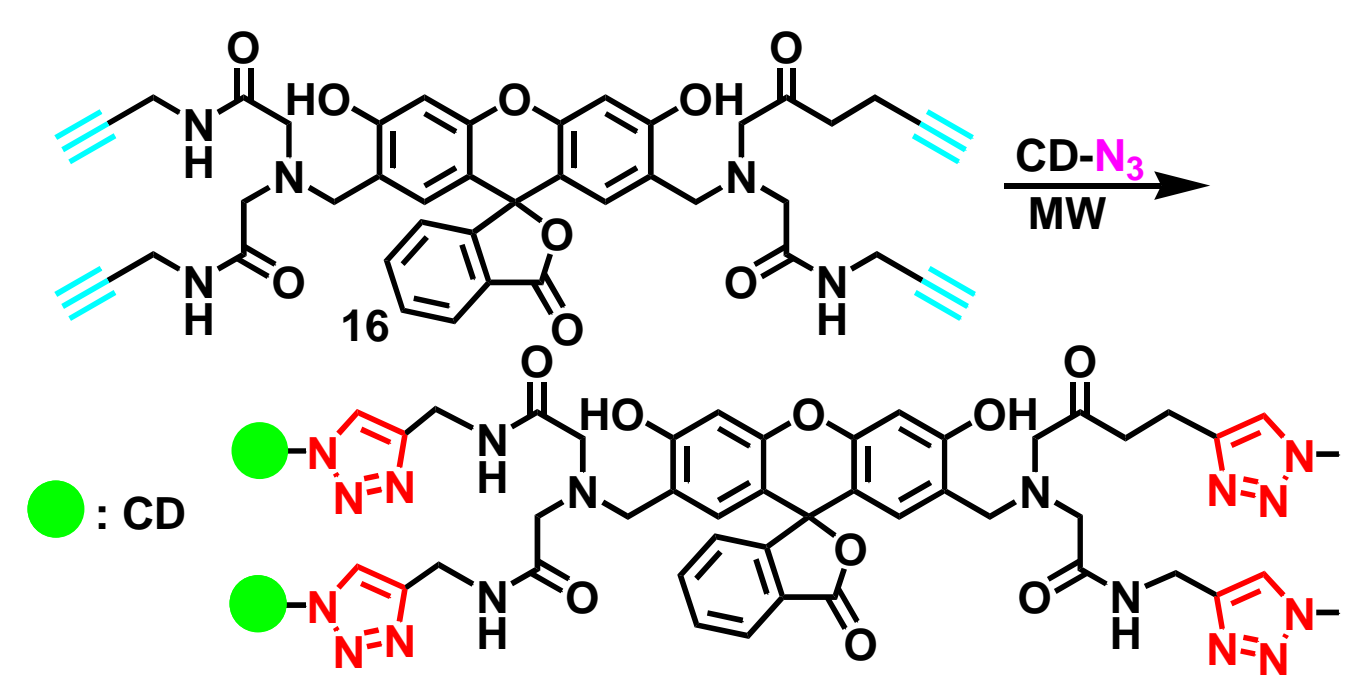

Scheme 16

$\operatorname{Lin}^{57}$ used $\mathrm{CuBr} / \mathrm{PMDETA}$ DMF catalytic system, make fourfold alkyne 17 derivatives containing ether bond (Scheme 17) and polyethylene glycol (peg) Permian nitrogen compounds and methyl acrylate click and atom transfer radical polymerization reaction at the same time, the liquid phase synthesis with interpenetrating polymer network structure of triazole macromolecules are more likely to be more used in biological gene carrier and medical drugs.

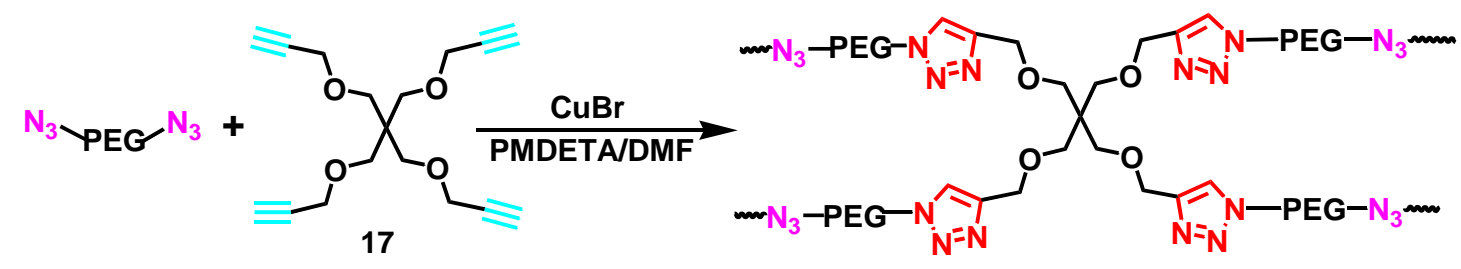

Scheme 17 


\subsection{Other alynls}

Thelakkat et $\mathrm{al}^{58}$ used $\mathrm{Cu}(\mathrm{I}) \mathrm{Br} / \mathrm{PMDETA} / \mathrm{THF}$ catalytic system to perform a 6-hour click reaction between polyalkylene $\mathbf{1 8}$ containing multifunctional groups (Scheme 18) and polybenzimidazole azide compound at room temperature. The liquid phase synthesis of polytriazole macromolecule molecular weight up to 15800 can be applied to semiconductor materials.

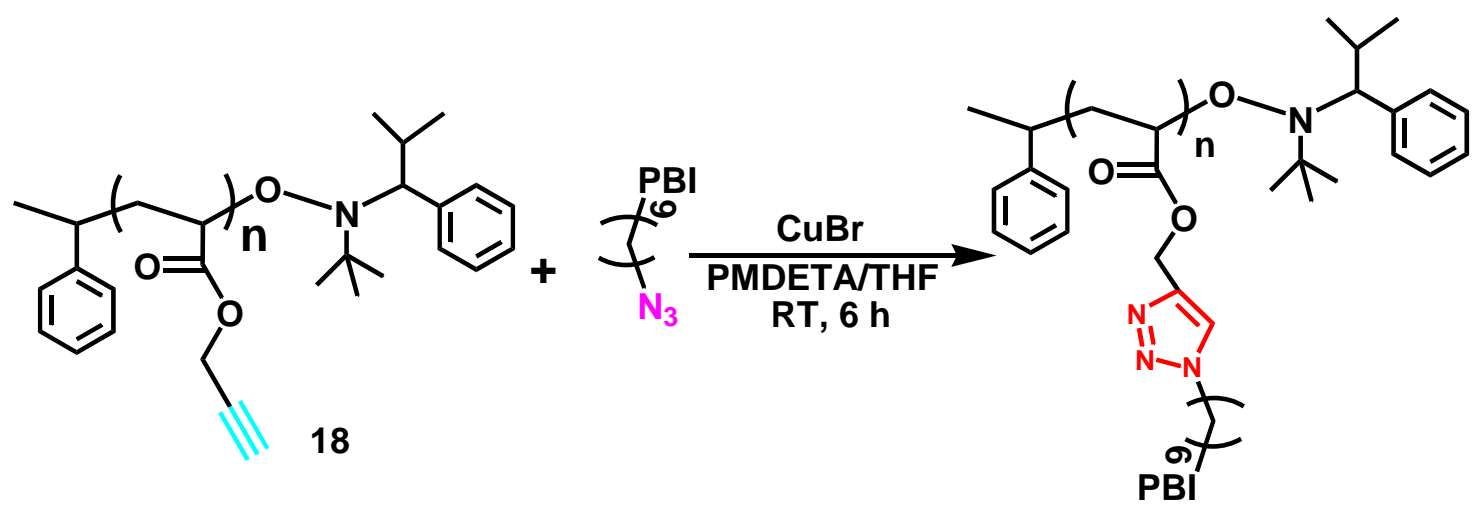

\section{Scheme 18}

Hawker $^{59}$ use $\mathrm{CuBr} / \mathrm{PMDETA} / \mathrm{DMF}$ catalytic system, make fourfold alkyne $\mathbf{1 9}$ derivatives containing ether bond (Scheme 19) and polyethylene glycol (peg) Permian nitrogen compounds and methyl acrylate click and atom transfer radical polymerization reaction at the same time, the liquid phase synthesis with interpenetrating polymer network structure of triazole macromolecules are more likely to be more used in biological gene carrier and medical drugs. 


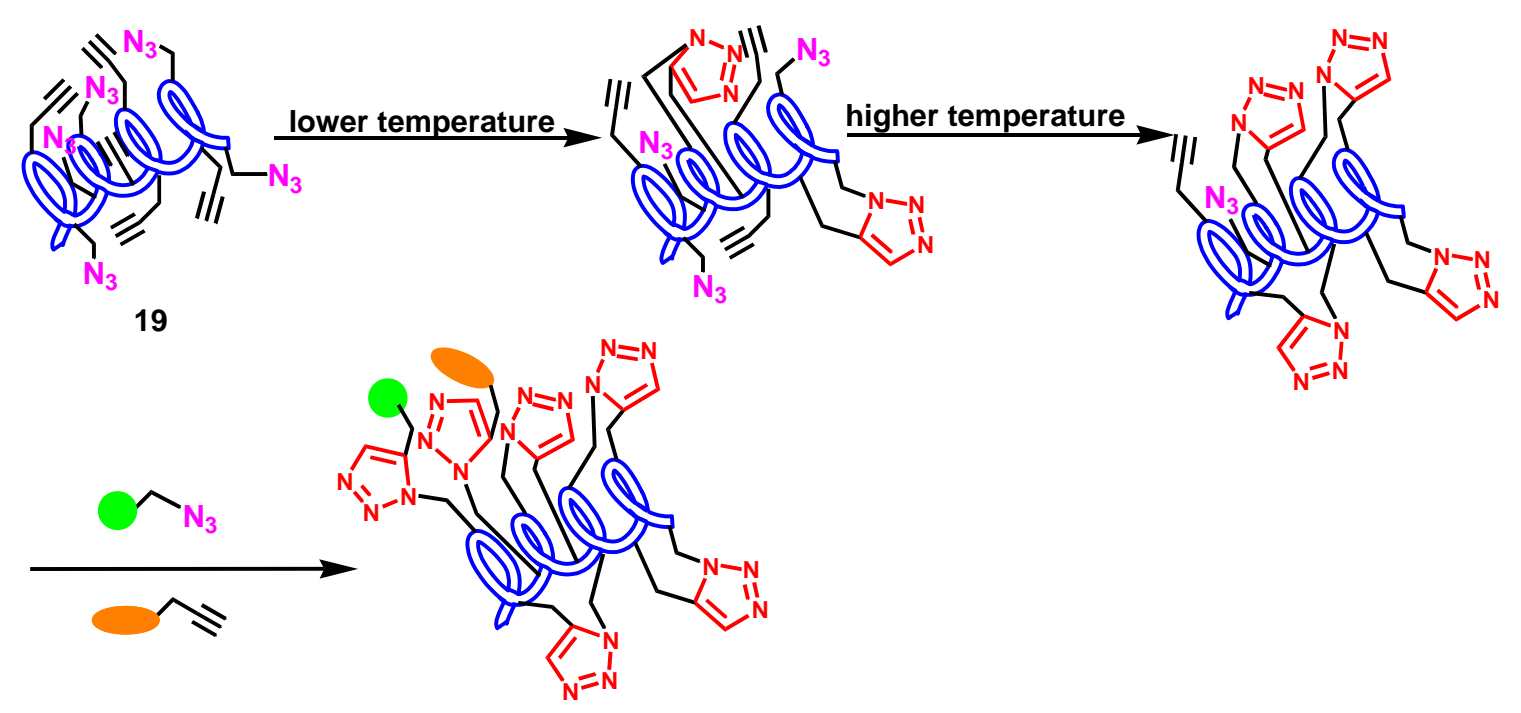

Scheme 19

\section{The effects of different compounds containing azide}

\section{1 mono-azide}

Gimeno $^{60}$ took advantage of $2 \mathrm{~mol} \% \mathrm{Cu}$ (I) complex/2, 6-dimethyl pyridine solution catalytic system, the mono azide 21 containing multifunctional group (Scheme 21) with multifunctional group's built-in single alkynes containing compound effectively the click reaction at room temperature, the liquid phase synthesis of iodine instead of triazole macromolecular yield above ninety percent, this new type of $\mathrm{Cu}$ (I) complex not only normal temperature stability, and is suitable for the mild reaction conditions, the catalyst click chemistry provides a new research direction. 


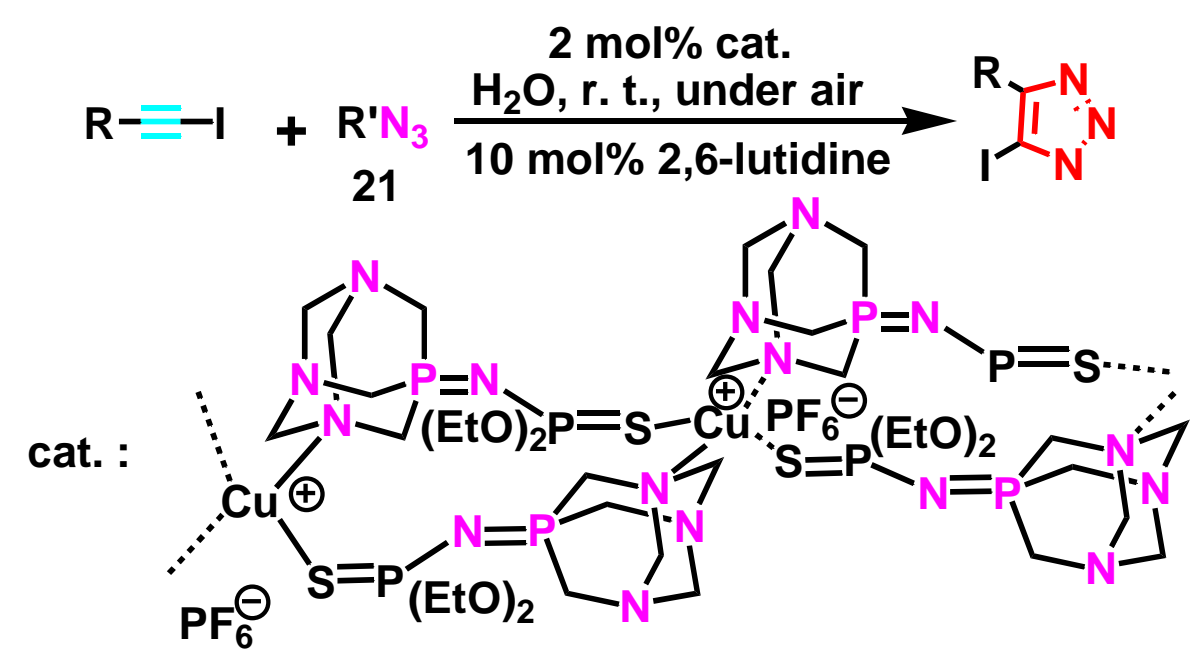

Scheme 21

Sharpless ${ }^{61}$ group based on $1 \mathrm{~mol} \% \mathrm{CuSO}_{4}$ and 5 mol \% sodium ascorbate catalytic system, $\mathrm{H}_{2} \mathrm{O}$ and ${ }^{t} \mathrm{BuOH}$ volume ratio of 2:1 in the mixed solvent, the single pile of azide 22 containing methylene phenyl (Scheme 22) and single alkynes containing phenyl methyl ether bond compounds at room temperature for 8 hours of the click reaction, the liquid phase synthesis of triazole macromolecular production rate is as high as $91 \%$.

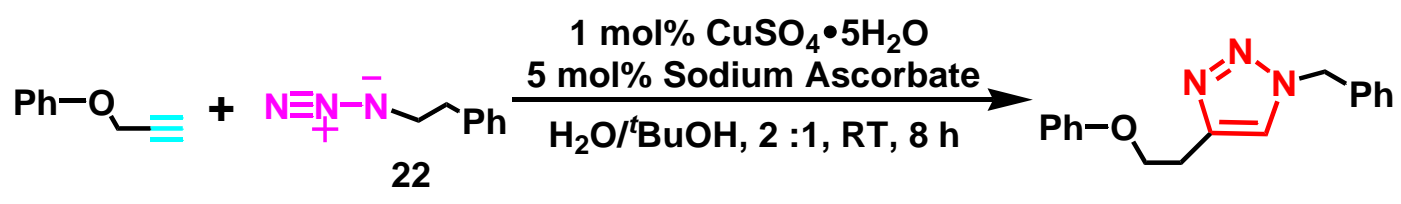

Scheme 22

\subsection{Per-azide}

Although mono-azide compounds have been used in triazole synthesis, few reports have been reported on polymeric triazole. Therefore, the main influence of different azide compounds on Click synthesis of polymer triazole is per-azide compounds. For example, Zhang ${ }^{62}$ reported other 
per-azide 23 (Scheme 23) containing ester key polyene key compounds under $30^{\circ} \mathrm{C}$ and alkynes efficient Click reaction of triazole macromolecular yield up to $98.6 \%$ more, molecular weight, the multi-functional team more triazole macromolecules can be widely applied to the adhesive materials, decoration materials, emulsifier, insulation material, gene transfer and drug synthesis, etc.

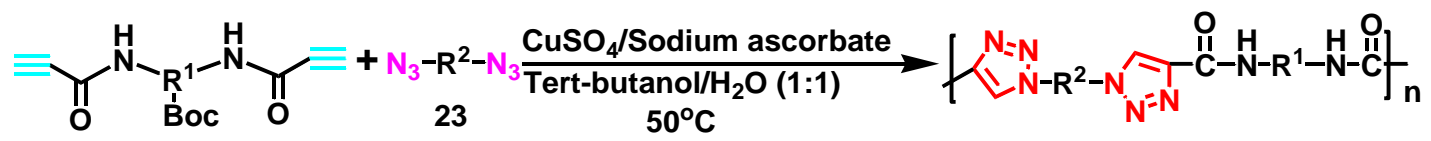

\section{Scheme 23}

Li et $\mathrm{al}^{63}$ demonstrated $\mathrm{CuSO}_{4} /$ ascorbic acid catalytic system, soluble in first four butyl alcohol and water mixed solvent volume ratio of 1 : 1 , heating to $50^{\circ} \mathrm{C}$ response after 24 hours, in methylene chloride and trifluoroacetic acid solvent volume ratio of 1: 1, the azide-compound 24 (Scheme 24) and diynes containing amide efficient Click reaction of the synthesis of triazole macromolecules, because has good biological compatibility, can be used as the carrier of gene transfer

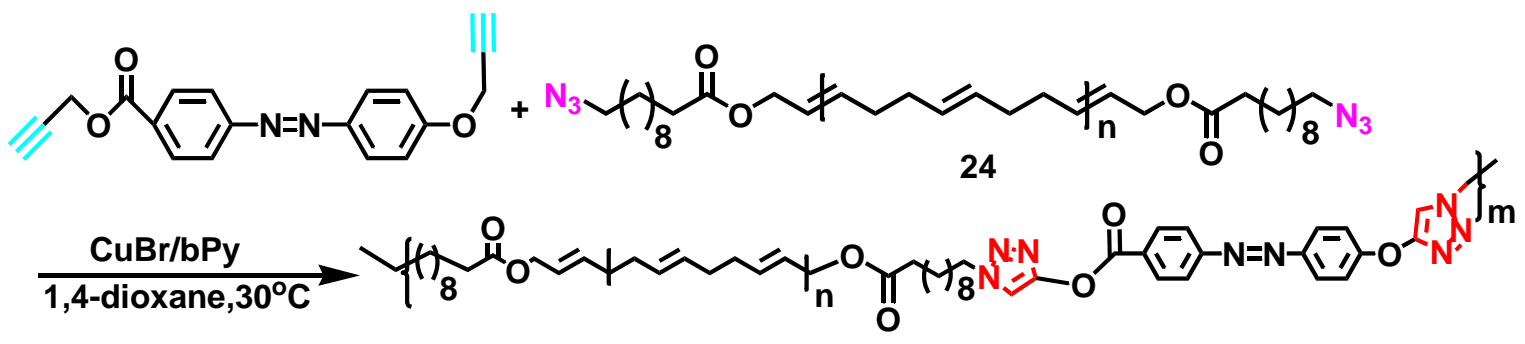

\section{Scheme 24}

Binder ${ }^{64}$ and others members showed $\mathrm{CuBr}\left(\mathrm{PPh}_{3}\right)_{3} / \mathrm{DMSO}$ catalytic system, and makes the low molecular weight compounds two tri-alkynes with a liquid more valence three arm type tri-azide 
polymer 25 (Scheme 25) effectively click reaction, liquid phase synthesis of triazole macromolecular molecular weight can be as high as $250000 \mathrm{Da}$, and the network are triazole is a kind of macromolecule material with characteristics of self-healing.

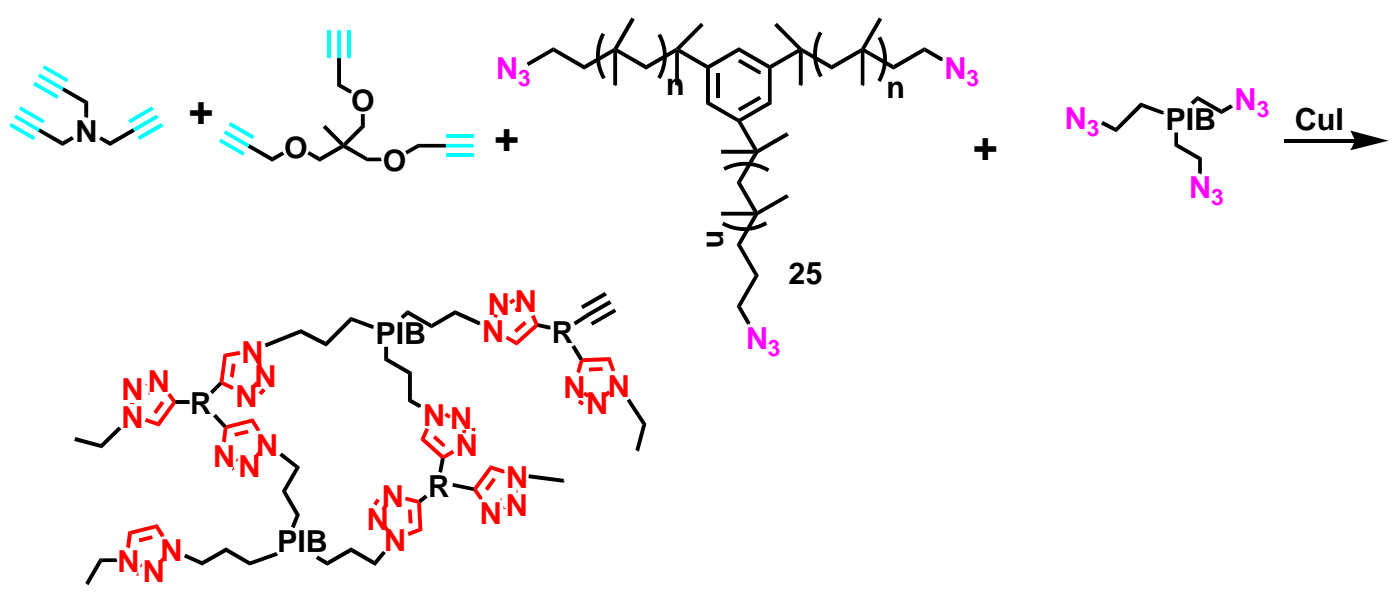

\section{Scheme 25}

\section{3 fourfold-azide}

Tsourkas ${ }^{65}$ and others using $\mathrm{CuSO}_{4} /$ sodium ascorbate catalytic system, made by the fourfoldazide 26 (Figure 1) modified superparamagnetic iron oxide nanoparticles with a single group of alkyne and by fluorescent penetrant modified human epidermal growth factor receptor for directional click reaction at room temperature, in this paper, the synthetic triazole macromolecular compounds and no further and more alkynes continue to generate much triazole macromolecules, so the molecular weight is not big, but the study found that the greater the concentration of this single triazole molecule of synthetic its fluorescence intensity, the greater the and it contains a variety of functional groups, Based on this, it can be applied in the field of diagnostic imaging and tumor drug delivery. 


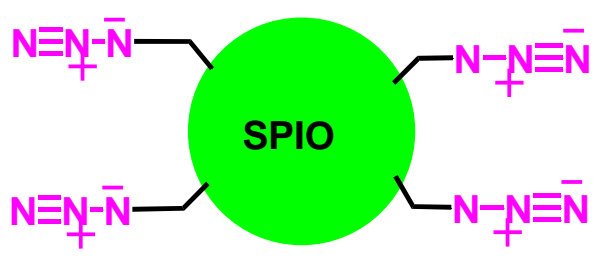

26

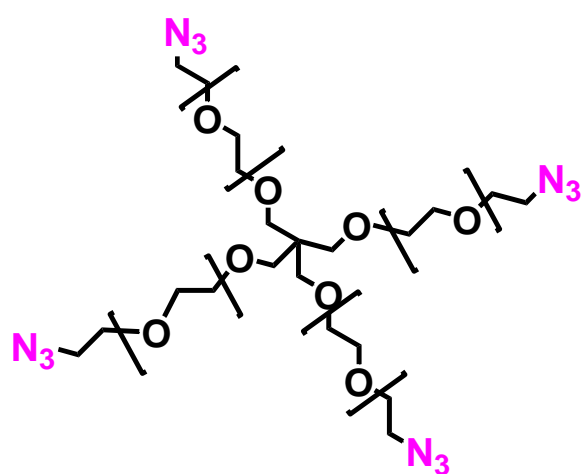

27

\section{Figure 1 Some fourfold-azides applying for polymeric synthesis via Click chemistry}

Kopecek $^{66}$ and others using $\mathrm{CuBr}$, L- ascorbic acid/DMF catalytic system, make similar to the end of the four arms containing more than fourfold azide 27 (Figure 1) based on polyethylene glycol (and its molecular weight is 2100 and $8800 \mathrm{Da}$ ) have base of alkyne polypeptide on both sides with high efficiency under the room temperature anaerobic reaction, click find of synthesis of this kind of many of the hydrogel swelling degree and degree of papain solution depends on the molecular weight of polyethylene glycol (peg), may be the future be manipulation of the mechanical performance and digestion performance of the design direction of hydrogel, Hydrogels were the first biomaterials to be used in clinical applications, followed by tissue engineering, drug delivery, sensing materials, diagnostics and microfluidics.

Zhao et $\mathrm{al}^{67}$ used a $10-20 \mathrm{~mol} \%\left(\mathrm{Ph}_{3} \mathrm{P}\right)_{3} \cdot \mathrm{CuBr}$ or $(\mathrm{EtO})_{3} \mathrm{P} \cdot \mathrm{CuI} / \mathrm{DIPEA}$ or DBU, toluene catalytic system to make the click reaction between glycine alkyne and terminal polyazides $\mathbf{2 8}$ (Scheme 26) efficiently at room temperature. The yield is usually up to $80 \%$.

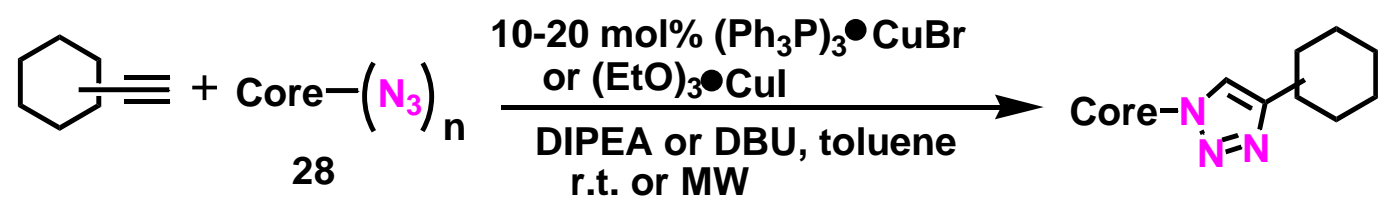




\section{Scheme 26}

\section{Conclusion and outlook}

In summary, click chemistry has been widely used in the research fields of polymer, surface modification and nanomaterials. ${ }^{68,69}$ It has been proved that click chemistry provided a powerful research tool for the design and development of new materials with its own characteristics of insensitivity to oxygen and water, good stereoselectivity of products and high yield. ${ }^{70-72}$ However, there are still some problems to be solved and the work to be done in the future aftermentioned. ${ }^{73-77}$

(i) Currently, the click reaction by cyclic acetylene and azide are relying on ring tension.

(ii) The catalytic system produces a certain degree of cytotoxicity, $\mathrm{Cu}(\mathrm{I})$ catalyst could result in aggregating nano-dispersion, limiting its application in vivo and nanometer.

(iii) CuAAC itself needs to be further studied and improved. What kind of solvent, temperature should be selected as the better reaction system? The problem with the source of $\mathrm{Cu}^{+}$in the reaction is that it's still online.

\section{ASSOCIATED CONTENT}

This information is available free of charge via the Internet at http://pubs.acs.org/.

\section{AUTHOR INFORMATION}

\section{Corresponding Author}


*E-mail: johnhome222@163.com. Tel: 86-757-82966588.

*E-mail: cdcever@163.com. Tel: 86-757-82966588.

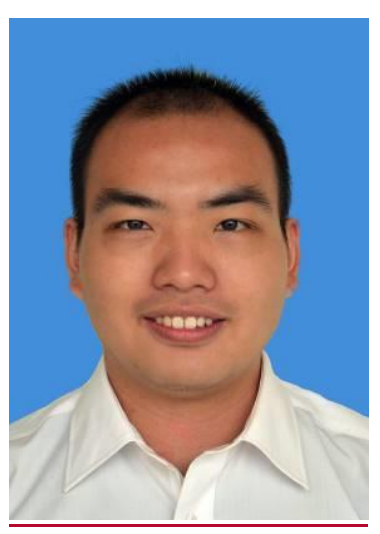

Dr Jingpei Huo was born in Chancheng district, Foshan, Guangdong China, in 1988. He received his bachelor's degree from Foshan University in 2010, a master's degree in 2013 from South China Normal University and a Ph.D. degree in 2016 from South China Technology University, working under the direction of Prof. Heping Zeng. From 2016 to forever, he was working in the group of Prof. Dongchu Chen at Foshan University. His current research interests lie in organic synthesis, especial for $N$-compounds. Some articles have been published on J. Mater. Chem. A, Appl. Catal B.-Environ., Macro. Rap. Comm., Polym. Chem., RSC adv., Appl. Surf. Sci. and ACS omega. and Ind. Eng. Chem. Res.

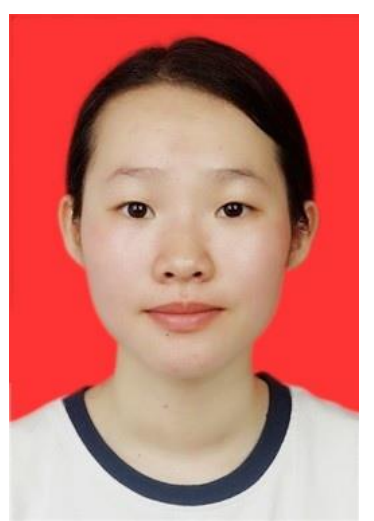

Shu-ni Wang was born in Heyuan, Guangdong China, in 2000. He received his bachelor's degree from Foshan University in 2021. His research focuses on the synthesis and activity of $\mathrm{N}-\mathrm{H}$ compounds 


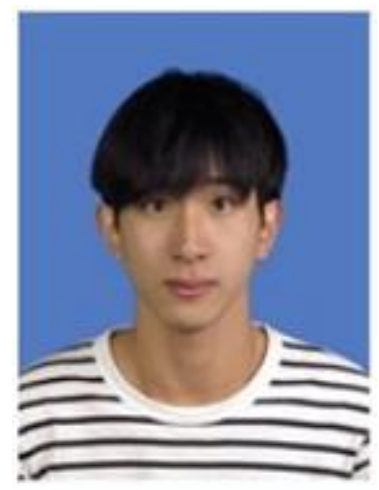

Yongpeng Liang was born in Chancheng district, Foshan, Guangdong China, in 1997. He received his bachelor's degree from Foshan University in 2019. His research focuses on the synthesis and activity of $\mathrm{N}-\mathrm{H}$ compounds.

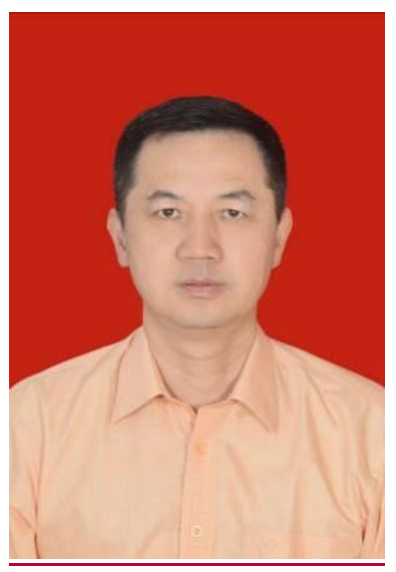

Dr Xiaohong Hu was born in Jingdezhen, Jiangxi China, in 1964. He received his Ph.D. degree in 2013 from the state key laboratory of organic geochemistry, Guangzhou Institute of Geochemistry, Chinese Academy of Sciences, working under the direction of Prof. Taicheng An. His current research interests lie in improving the photodegradation efficiency of dye, especially the modification of $\mathrm{TiO}_{2}$.

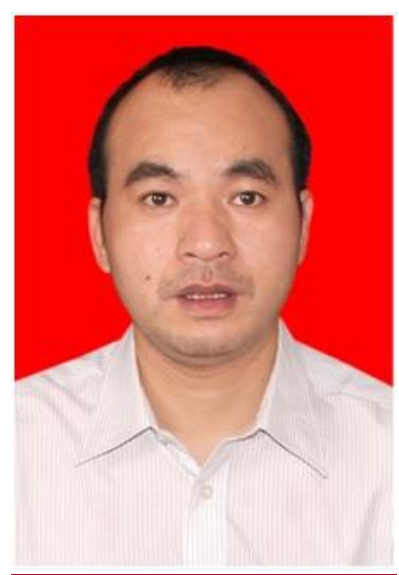

Dr Qianjun Deng was born in Chengzhou, Hunan China, in 1968. He received his Ph.D. degree in 2010 from Central South University. His current research interests lie in enhancing the photocatalytic efficiency of photocatalysts, including the synthesis and modification of metal complex. 


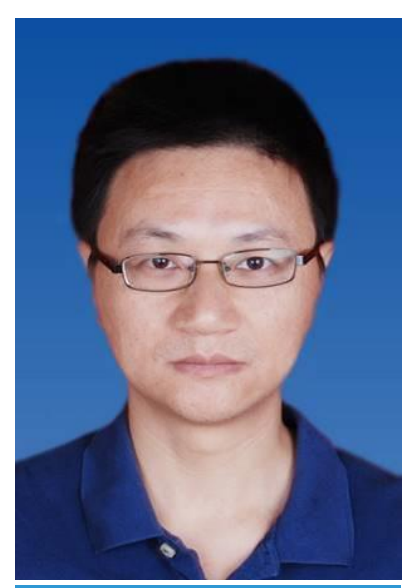

Dr Dongchu Chen was born in Chongyi, Jiangxi China, in 1972. He earned his chemistry Ph.D. from Huazhong University of Science and Technology. He did his postdoctoral work at the South China University of Technology, and is currently professor at the Foshan University. He is a researcher of metal composite, especially the surface modification of organic material, some articles have been published on Polym. Chem., RSC adv., Appl. Surf. Sci. and ACS omega.

\section{Author Contributions}

Both ${ }^{\dagger}$ J. Huo and D. Chen were equally to this work. J. Huo, S. Wang, X. Hu, Q. Deng and D. Chen have designed and prepared the manuscript. All authors read and approved the final manuscript.

\section{Notes}

The authors have declared no competing financial interest.

\section{ACKNOWLEDGMENT}

We are grateful to the High-Level Talent Start-Up Research Project of Foshan University (cgg040947), Guangdong Natural Science Foundation of China (Grant No. 2018A030310350, 2017A030313307), the National Natural Science Foundation of China (No. 51702051), the key Project of Department of Education of Guangdong Province (2016GCZX008), the key Research 
Platform Project of Department of Education of Guangdong Province (gg041002), the Project of Engineering Research Center of Foshan (20172010018) and Education Department Foundation of Guangdong province (No. 2016KTSCX151) for financial support.

\section{REFERENCES}

[1] Alvarez-Castelao, B.; Schanzenbächer, C. T.; Langer, J. D.; Schuman, E. M. Cell-typespecific metabolic labeling, detection and identification of nascent proteomes in vivo. Nature Protoc. 2019, 14, 556-575.

[2] Haugland, M. M.; Borsley, S.; Cairns-Gibson, D. F.; Elmi, A.; Cockroft, S. L. Synthetically diversified protein nanopores: Resolving click reaction mechanisms. ACS Nano 2019, in press (DOI: 10.1021/acsnano.8b08691).

[3] Deepak, V. D.; Mahmud, I.; Gauthier, M. Synthesis of carboxylated derivatives of poly(isobutylene-co-isoprene) by azide-alkyne "click" chemistry. Polymer J. 2019, 51, 327335.

[4] Huang, D.; Liu, Y.; Qin, A. J.; Tang, B. Z. Structure-property relationship of regioregular polytriazoles produced by ligand-controlled regiodivergent $\mathrm{Ru}(\mathrm{II})$-catalyzed azide-alkyne click polymerization. Macromolecules 2019, 52, 1985-1992.

[5] Liu, E.-C.; Topczewski, J. J. Enantioselective copper catalyzed alkyne-azide cycloaddition by dynamic kinetic resolution. J. Am. Chem. Soc. 2019, in press (DOI: 10.1021/jacs.9b01091). 
[6] Bagheri, S.; Jamal, N.; Halilu, A.; TermehYousefi, A. Novel rGO-T-C(n) nanosheets developed via click chemistry as a lubricant anti-wear additive. Sci. Rep. 2018, 8, 6221-6229.

[7] Nguyen, M. L.; Byun, J.; Kim, S.; Hyun, J. W.; Hur, K.; Shin, T. J.; Cho, B.-K. Ferroelectrically switching helical columnar assembly comprising cisoid conformers of a 1,2,3-triazole-based liquid crystal. Angew. Chem. Int. Ed. 2019, 58, 2749-2753.

[8] Saha, P.; Panda, D.; Dash, J. The application of click chemistry for targeting quadruplex nucleic acids. Chem. Commun. 2019, 55, 731-750.

[9] Thanh, N. D.; Hai, D. S.; Bich, V. T. N.; Hien, P. T. T.; Duyen, N. T. K.; Mai, N. T.; Dung, T. T.; Toan, V. N.; Van, H. T. K.; Dang, L. H.; Toan, D. N.; Van, T. T. T. Efficient click chemistry towards novel 1H-1,2,3-triazole-tethered 4H-chromene-d-glucose conjugates: Design, synthesis and evaluation of in vitro antibacterial, MRSA and antifungal activities. Eur. J. Med. Chem. 2019, 167, 454-471.

[10]Xu, Y.; Zhang, K. X.; Reghu, S.; Lin, Y. C.; Chan-Park, M. B.; Liu, X.-W. Synthesis of antibacterial glycosylated polycaprolactones bearing imidazoliums with reduced hemolytic activity. Biomacromolecules 2019, 20, 949-958.

[11]Cheng, T.-Y.; Lee, J.-H.; Chen, C.-H.; Chen, P.-H.; Wang, P.-S.; Lin, C.-E.; Lin, B.-Y.; Lan, Y.-H.; Hsieh, Y.-H.; Huang, J.-J.; Lu, H.-F.; Chao, I.; Leung, M.-k.; Chiu, T.-L.; Lin, C.-F. Carrier transport and recombination mechanism in blue phosphorescent organic lightemitting diode with hosts consisting of cabazole- and triazole-moiety. Sci. Rep. 2019, 9, 3654-3665. 
[12] Steiner, S.; Wolf, J.; Glatzel, S.; Andreou, A.; Granda, J. M.; Keenan, G.; Hinkley, T.; Aragon-Camarasa, G.; Kitson, P. J.; Angelone, D.; Cronin, L. Organic synthesis in a modular robotic system driven by a chemical programming language. Science 2019, 363, eaav2211-eaav2221.

[13]Patil, P. C.; Tan, J. L.; Demuth, D. R.; Luzzio, F, A. 'Second-generation’ 1,2,3-triazolebased inhibitors of Porphyromonas gingivalis adherence to oral streptococci and biofilm formation. Med. Chem. Commun. 2019, 10, 268-279.

[14]Acik, G.; Cansoy, C. E.; Tasdelen, M. A. Synthesis of fluorinated polypropylene using CuAAC click chemistry. J. Appl. Polym. Sci. 2019, 136, 47072-47078.

[15] Ashooriha, M.; Khoshneviszadeh, M.; Khoshneviszadeh, M.; Moradi, S. E.; Rafiei, A.; Kardan, M.; Emam, S. 1,2,3-Triazole-based kojic acid analogs as potent tyrosinase inhibitors: Design, synthesis and biological evaluation. Bioorgan. Chem. 2019, 82, 414-422.

[16]Agnew, H. D.; Coppock, M. B.; Idso, M. N.; Lai, B. T.; Liang, J. X.; McCarthy-Torrens, A. M.; Warren, C. M.; Heath, J. R. Protein-catalyzed capture agents. Chem. Rev. 2019, in press (DOI: 10.1021/acs.chemrev.8b00660).

[17]Babaei, N.; Yeganeh, H.; Gharibi, R. Anticorrosive and self-healing waterborne poly(urethane-triazole) coatings made through a combination of click polymerization and cathodic electrophoretic deposition. Euro. Polym. J. 2019, 112, 636-647.

[18] Saric, I.; Peter, R.; Markovic, M. K.; Badovinac, I. J.; Rogero, C.; Ilyn, M.; Knez, M.; Ambrožić, G. Introducing the concept of pulsed vapor phase copper-free surface clickchemistry using the ALD technique. Chem. Commun. 2019, 55, 3109-3112. 
[19]Li, P.-Z.; Wang, X.-J.; Zhao, Y. L. Click chemistry as a versatile reaction for construction and modification of metal-organic frameworks. Coordin. Chem. Rev. 2019, 380, 484-518

[20]He, C.; Janzen, R.; Bai, S.; Teplyakov, A. V. “Clickable” metal-oxide nanomaterials surface-engineered by gas-phase covalent functionalization with prop-2-ynoic acid. Chem. Mater., 2019, in press (DOI: 10.1021/acs.chemmater.8b05124).

[21]Chen, L. H.; Keller, L. J.; Cordasco, E. A.; Bogyo, M.; Lentz, C. S. Single-cell phenotypic characterization of Staphylococcus aureus with fluorescent triazole urea activity-based probes. Angew. Chem. Int. Ed. 2019, in press (DOI: 10.1002/anie.201900511).

[22]Brandhofer, T.; Özdemir, A.; Gini, A.; Mancheño, O. G. Double Cu-catalyzed direct Csp3-H azidation/CuAAC reaction: A direct approach towards demanding triazole conjugates. Chem. A Eur. J. 2019, 25, 4077-4086.

[23]Babu, J.; Ganesan, S.; Kumar, K. A.; Karuppusamy, M.; Pandurangan, A.; Rajakumar, P. Cyclohexadienone core 3,6-di-tert-butylcarbazole decorated triazole bridged dendrimers: synthesis, photophysical and electrochemical properties and application as an additive in dye-sensitized solar cells. New J. Chem. 2019, 43, 4036-4048.

[24]Alvarez-Dorta, D.; Thobie-Gautier, C.; Croyal, M.; Bouzelha, M.; Mével, M.; Deniaud, D.; Boujtita, M.; Gouin, S. G. Electrochemically promoted tyrosine-click-chemistry for protein labeling. J. Am. Chem. Soc. 2018, 140, 17120-17126.

[25]Riva, B.; Griglio, A.; Serafini, M.; Cordero-Sanchez, C.; Aprile, S.; Paola, R. D.; Gugliandolo, E.; Alansary, D.; Biocotino, I.; Lim, D.; Grosa, G.; Galli, U.; Niemeyer, B.; Sorba, G.; Canonico, P. L.; Cuzzocrea, S.; Genazzani, A. A.; Pirali, T. Pyrtriazoles, a novel 
class of store-operated calcium entry modulators: Discovery, biological profiling, and in vivo proof-of-concept efficacy in acute pancreatitis. J. Med. Chem. 2018, 61, 9756-9783.

[26]Huo, J. P.; Zou, W. Y.; Zhang, Y. B.; Hu, X. H.; Deng, Q. J.; Chen, D. C. Facile preparation of bithiazole-based material for inkjet printed light-emitting electrochemical cell. $R S C A d v$. 2019, 9, 6163-6168.

[27]Huo, J. P.; Deng, Q. J.; Fan, T.; He, G. Z.; Hu, X. H.; Hong, X. X.; Chen, H.; Luo, S. H.; Wang, Z. Y.; Chen, D. C. Advances in polydiacetylene development for the design of side chain groups in smart material applications-a mini review. Polym. Chem. 2017, 8, 74387445.

[28]Huo, J. P.; Hu, H. W.; Zhang, M.; Hu, X. H.; Chen, M.; Chen D. C.; Liu, J. W.; Xiao, G. F.; Wang, Y.; Wen, Z. L. A mini review of the synthesis of poly-1,2,3-triazole-based functional materials. $R S C A d v$. 2017, 7, 2281-2287.

[29]Huo, J. P.; Hu, H. W.; He, G. Z.; Hong, X. X.; Yang, Z. H.; Luo, S. H.; Ye, X. F.; Li, Y. L.; Zhang, Y. B.; Zhang, M.; Chen, H.; Fan, T.; Zhang, Y. Y.; Xiong, B. Y.; Wang, Z. Y.; Zhu, Z. B.; Chen, D. C. High temperature thermochromic polydiacetylenes: Design and colorimetric properties. Appl. Surf. Sci. 2017, 423, 951-956.

[30]Huo, J. P.; Hu, Z. D.; Chen, D. C.; Luo, S. H.; Wang, Z. Y.; Gao, Y. H.; Zhang, M.; Chen, H. Preparation and characterization of poly-1,2,3-triazole with chiral 2(5H)-furanone moiety as potential optical brightening agents. ACS Omega 2017, 2, 5557-5564. 
[31]Huo, J. P.; Deng, G. H.; Wu, W.; Xiong, J. F.; Zhong, M. L.; Wang, Z. Y. Electrophoretic deposition polymerization of diacetylenes with tunable structure. Macromol. Rapid Commun. 2013, 34, 1779-1784.

[32]Lee, D. J.; Cameron, A. J.; Wright, T. H.; Harris, P. W. R.; Brimble, M. A. A synthetic approach to 'click' neoglycoprotein analogues of EPO employing one-pot native chemical ligation and CuAAC chemistry. Chem. Sci. 2019, 10, 815-828.

[33]I. L. K. Wong, X. Z. Zhu, K.-F. Chan, M. C. Law, A. M. Y. Lo, X. S. Hu, L. M. C. Chow, T. H. Chan, Discovery of novel flavonoid dimers to reverse multidrug resistance protein 1 (MRP1, ABCC1) mediated drug resistance in cancers using a high throughput platform with “Click chemistry”. J. Med. Chem., 2018, 61, 9931-9951.

[34] Yuan, L.; Zhang, Y. Q.; Wang, Z. K.; Han, Y. M.; Tang, C. B. Plant oil and lignin-derived elastomers via thermal azide-alkyne cycloaddition click chemistry. ACS Sustainable Chem. Eng. 2019, 7, 2593-2601.

[35] Chandrasekaran, K. S.; Rentmeister, A. Clicking a fish: Click chemistry of different biomolecules in danio rerio. Biochemistry 2019, 58, 24-30.

[36]Dadfar, S. M. M.; Sekula-Neuner, S.; Bog, U.; Trouillet, V.; Hirtz, M. Site-specific surface functionalization via microchannel cantilever spotting ( $\mu \mathrm{CS}$ ): Comparison between azidealkyne and thiol-alkyne click chemistry reactions. Small 2018, 14, 1800131-1800140.

[37] Song, H. B.; Brady, A. B.; Worrell, T.; Cook, W. D.; Bowman, C. N. Photopolymerized triazole-based glassy polymer networks with superior tensile toughness. Adv. Funct. Mater. 2018, 28, 1801095-1801103. 
[38]Benjamin, M. S. H.; Benedikt, M. S.; Flöser, M.; Meißner, B. S. N. E.; Engesser, T. A.; Tuczek, F. Click. coordinate. catalyze. using CuAAC click ligands in small-molecule model chemistry of tyrosinase. Chem CatChem 2018, 10, 5402-5405.

[39] Wang, Y. L.; Astruc, D.; Abd-El-Aziz, A. S. Metallopolymers for advanced sustainable applications. Chem. Soc. Rev. 2019, 48, 558-636.

[40]Chen, H. M.; Li, Y. L.; Wu, H.; Sun, N. R.; Deng, C. H. Smart hydrophilic modification of magnetic mesoporous silica with zwitterionic l-cysteine for endogenous glycopeptides recognition. ACS Sustainable Chem. Eng. 2019, 7, 2844-2851.

[41]Li, Z. B.; Zhang, Y.; Zhu, L. R.; Shen, T.; Zhang, H. Q. Efficient synthesis of photoresponsive azobenzene-containing side-chain liquid crystalline polymers with high molecular weights by click chemistry. Polym. Chem. 2010, 1, 1501-1511.

[42]Wu, D. X.; Song, X. H.; Tang, T.; Zhao, H. Y. Macromolecular brushes synthesized by “'grafting from” approach based on "Click Chemistry' and RAFT polymerization. J. Polym. Sci. Pol. Chem. 2009, 48, 443-453.

[43] Montagnat, O. D.; Lessene, G.; Hughes, A. B. Synthesis of azide-alkyne fragments for "Click" chemical applications. Part2. Formation of oligomers from orthogonally protected chiral trialkyl-silylhomopropargyl azides and homopropargyl alcohols. J. Org. Chem. 2010, 75, 390-398.

[44]Zhang, W. A.; Muller, A. H. E. A "Click Chemistry" approach to linear and star-shaped telechelic POSS-containing hybrid polymers. Macromolecules 2010, 43, 3148-3152. 
[45]Lang, C.; Voll, D.; Inglis, A. J.; Dingenouts, N.; Goldmann, A. S.; Barner, L.; Kowollik, C. B. An access route to polyferrocenes via modular conjugation. Macromol. Chem. Phys. 2011, $212,831-839$.

[46]Huang, J. J.; Xu, W. L. Efficient synthesis of zwitterionic sulfobetaine group functional polyurethanes via "Click" reaction. J. Appl. Polym. Sci. 2011, 122, 1251-1257.

[47] Wang, Y. K.; Wang, D. X.; Han, J. J.; Feng, S. Y. Facile synthesis of $\sigma-\pi$ conjugated organosilicon polymers via Click polymerization. J. Organomet. Chem. 2011, 696, 18741878.

[48]Eissa, A. M.; Khosravi, E. Synthesis of a new smart temperature responsive glycopolymer via click-polymerisation. Eur. Polym. J. 2011, 47, 61-69.

[49] Yao, R. X.; Kong, L.; Yin, Z. S.; Qing, F. L. Synthesis of novel aromatic ether polymers containing perfluorocyclobutyl and triazole units via click chemistry. J. Fluorine Chem. 2008, 129, 1003-1010.

[50] Gungor, E.; Bilir, C.; Durmaz, H.; Hizal, G.; Tunca, U. Star polymers with POSS via azidealkyne click reaction. J. Polym. Sci., Part A: Polym. Chem. 2009, 47, 5947- 5953.

[51]Jain, S. L.; Modak, A.; Bhaumik, A. A novel mesoporous silica-grafted organocatalyst for the Michael addition reaction, synthesized via the click method. Green Chem. 2011, 13, 586590.

[52]Karskela, M.; Helkearo, M.; Virta, P.; Lonnberg, H. Synthesis of oligonucleotide glycoconjugates using sequential click and oximation ligations. Bioconjugate Chem. 2010, 21, 748-755. 
[53]Qin, A. J.; Lam, J. W. Y.; Tang, B. Z. Click polymerization: progresses, challenges, and opportunities. Macromolecules 2010, 43, 8693-8702.

[54]Xie, J. D.; Hu, L. H.; Shi, W. F.; Deng, X. X.; Cao, Z. Q.; Shen, Q. S. Synthesis and nonlinear optical properties of hyperbranched polytriazole containing second-order nonlinear optical chromophore. J. Polym. Sci. Part B: Polym Phys. 2008, 46, 1140-1148.

[55]Katritzky, A. R.; Sakhuja, R.; Huang, L. C.; Guanda, R.; Wang, L.; Jackson, D. C.;

Ciaramitaro, D. A.; Bedford, C. D.; Duran, R. S. Effect of filler loading on the mechanical properties of crosslinked 1,2,3-triazole polymers. J. Appl. Polym. Sci. 2010, 118, 121-127.

[56]Bohm, I.; Isenbugel, K.; Ritter, H.; Branscheid, R.; Kolb, U. Fluorescent nanowires selfassembled through host-guest interactions in modified calcein. Angew. Chem. Int. Ed. 2011, $50,7407-7409$.

[57] Yao, F.; Xu, L. Q.; Fu, G. D.; Lin, B. P. Sliding-graft interpenetrating polymer networks from simultaneous "Click Chemistry" and atom transfer radical polymerization. Macromolecules 2010, 43, 9761-9770.

[58]Lang, A. S.; Neubig, A.; Sommer, M.; Thelakkat, M. NMRP versus "click" chemistry for the synthesis of semiconductor polymers carrying pendant perylene bisimides. Macromolecules 2010, 43, 7001-7010.

[59] Spruell, J.M.; Wolffs, M.; Leibfarth, F.A.; Stahl, B. C.; Heo, J.; Connal, L. A.; Hu, J.; Hawker, C. J. Reactive, Multifunctional polymer films through thermal cross-linking of orthogonal click groups. J. Am. Chem. Soc. 2011, 133, 16698-16706. 
[60]Alvarez, J. G.; Diez, J.; Gimeno, J. A highly efficient copper(I) catalyst for the 1,3-dipolar cycloaddition of azides with terminal and 1-iodoalkynes in water: regioselective synthesis of 1,4-disubstituted and 1,4,5-trisubstituted 1,2,3-triazoles. Green Chem. 2010, 12, 2127-2130.

[61]Rostovtsev, V. V.; Green, L. G.; Fokin, V. V.; Sharpless, K. B. A stepwise Huisgen cycloaddition process: copper (I)-catalyzed regioselective "Ligation" of azides and terminal alkynes. Angew. Chem. Int. Ed. 2002, 41, 2596-2599.

[62]Ding, L.; Zhang, L. Y.; Huang, W.; Xie, M. R.; Zhang, Y. Q. New azo-chromophorecontaining multiblock poly(butadiene)s synthesized by the combination of ring-opening metathesis polymerization and click chemistry. Polymer 2010, 51, 1285-1292.

[63]Gao, Y.; Chen, L. L.; Zhang, Z. W.; G, W. W.; L, Y. P. Linear cationic click polymer for gene delivery: synthesis, biocompatibility, and in vitro transfection. Biomacromolecules 2010, $11,3102-3111$.

[64] Gragert, M..; Schunack, M.; Binder, W. H. Azide/Alkyne-"click"-reactions of encapsulated reagents: toward self-healing materials. Macromol. Rapid Commun. 2011, 32, 419- 425.

[65]Elias, D. R.; Cheng, Z. L.; Tsourkas, A. An intein-mediated site-specific click conjugation strategy for improved tumor targeting of nanoparticle systems. Small 2010, 6, 2460-2468.

[66] Yang, J. Y.; Jacobsen, M. T.; Pan, H. Z.; Kopecek, J. Synthesis and characterization of enzymatically degradable PEG-based peptide-containing hydrogelsa. Macromol. Biosci. $2010,10,445-454$.

[67]Kolb, H. C.; Sharpless, K. B. The growing impact of click chemistry on drug discovery. Drug Discov. Today 2003, 8, 1128-1137. 
[68]Hao, N. R.; Duan, X. Z.; Yang, H. J.; Umair, A.; Zhu, M.; Zaheer, M.; Yang, J. X.; Li, L. W. How does the branching effect of macromonomer influence the polymerization, structural features, and solution properties of long-subchain hyperbranched polymers? Macromolecules 2019, 52, 1065-1082.

[69] Swisher, J. H.; Nowalk, J. A.; Meyer, T. Y.; Property impact of common linker segments in sequence-controlled polyesters. Polym. Chem. 2019, 10, 244-252.

[70]Liu, R. J.; Liu, X.; Ouyang, K. B.; Yan, Q. Catalyst-free click polymerization of $\mathrm{CO}_{2}$ and lewis monomers for recyclable C1 fixation and release. ACS Macro Lett. 2019, 8, 200-204.

[71]Han, J.; Kim, K.; Kim, J.; Kim, S.; Choi, S.-W.; Lee, H.; Kim, J.-j.; Kim, T.-H.; Sung, Y.-E.; Lee, J.-C. Cross-linked highly sulfonated poly(arylene ether sulfone) membranes prepared by in-situ casting and thiol-ene click reaction for fuel cell application. J. Membr. Sci. 2019, 579, 70-78.

[72]Ho, J.-H.; Stahl, E. L.; Schmid, C. L.; Scarry, S. M.; Aubé, J.; Bohn, L. M. G protein signaling-biased agonism at the k-opioid receptor is maintained in striatal neurons. Sci. Signal. 2018, 11, eaar4309-eaar4310.

[73]Kwan, C.-S.; Zhao, R. D.; Hove, M. A. V.; Cai, Z. W.; Leung, K. C.-F. Higher-generation type III-B rotaxane dendrimers with controlling particle size in three-dimensional molecular switching. Nature Commun. 2018, 9, 497-505.

[74] Guselnikova, O.; Postnikov, P.; Chehimi, M. M.; Kalachyovaa, Y.; Svorcik, V.; Lyutakov, O. Surface plasmon-polariton: A novel way to initiate azide-alkyne cycloaddition. Langmuir 2019, 35, 2023-2032. 
[75]Hong, T. T.; Liu, W. F.; Li, M.; Chen, C. P. Click chemistry at the microscale. Analyst 2019, $144,1492-1512$.

[76]Huo, J. P.; Zhang, Y. B.; Zou, W. Y.; Hu, X. H.; Deng, Q. J.; Chen, D. C. Mini-review in engineering approach towards selective of transition metal complex-based catalyst for photocatalytic $\mathrm{H}_{2}$ production. Catal. Sci. Technol., 2019, in press (DOI: 10.1039/C8CY02581A).

[77]Huo, J. P.; Zou, W. Y.; Zhang, Y. B.; Hu, X. H.; Deng, Q. J.; Chen, D. C. Facile preparation of bithiazole-based material for inkjet printed light-emitting electrochemical cell. RSC Adv., 2019, 9, 6163-6168 